\title{
COMPARISON OF SODIUM ZIRCONIUM PHOSPHATE-STRUCTURED HLW FORMS AND SYNROC FOR HIGH-LEVEL NUCLEAR WASTE IMMOBILIZATION
}

V.N. ZYRYANOV,

Chemical Technology Division

Argonne National Laboratory

9700 South Cass Avenue

Argonne, Illinois 60439-4837

zyryanov@cmt.anl.gov

and

E. R. VANCE

Materials Division



3)

ANSTO

Menai, N.S.W. 2234, Australia

\section{DISCLAIMER}

This report was prepared as an account of work sponsored by an agency of the United States Government. Neither the United States Government nor any agency thereof, nor any of their employees, makes any warranty, express or implied, or assumes any legal liability or responsibility for the accuracy, completeness, or usefulness of any information, apparatus, product, or process disclosed, or represents that its use would not infringe privately owned rights. Reference herein to any specific commercial product, process, or service by trade name, trademark, manufacturer, or otherwise does not necessarily constitute or imply its endorsement, recommendation, or favoring by the United States Government or any agency thereof. The views and opinions of authors expressed herein do not necessarily state or reflect those of the United States Government or any agency thereof.

The submitted manuscript has been authored by a contractor of the U.S. Government under contract No. W-31-109-ENG-38. Accordingly, the U.S. Government retains a nonexclusive, royalty-free license to publish or reproduce the published form of this contribution, or allow others to do so, for U.S. Government purposes.

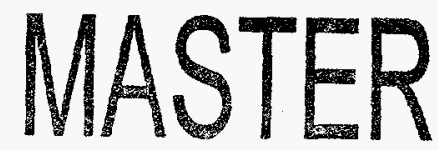

To be Presented at:

Material Research Society Symposium

Boston, MA

December 1-6, 1996

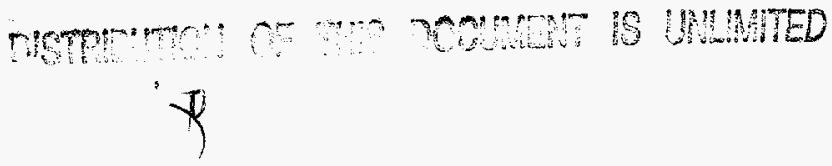




\section{DISCLAIMER}

Portions of this document may be illegible in electronic image products. Images are produced from the best available original document. 
COMPARISON OF SODIUM ZIRCONIUM PHOSPHATE-STRUCTURED HLW FORMS AND SYNROC FOR HIGH-LEVEL NUCLEAR WASTE IMMOBILIZATION

V.N. ZYRYANOV, Chemical Technology Division, Argonne National Laboratory, 9700 South Cass Avenue, Argonne, Illinois 60439-4837, zyryanov@cmt.anl.gov, and E. R. VANCE, Materials Division, ANSTO, Menai, N.S.W. 2234, Australia.

\section{ABSTRACT}

The incorporation of (a) $\mathrm{Cs} / \mathrm{Sr}$ as simulated heat-generating isotopes contained in Purex reprocessing waste, (b) simulated actinides, and (c) simulated Purex waste in sodium zirconium phosphate (NZP) has been studied. The samples were prepared by sintering, by hot pressing and by hot isostatic pressing in metal bellows containers. The short-term chemical durability of the phosphate-based material containing Purex waste was within an order of magnitude of that for Synroc-C, as measured by 7 -day MCC-1 tests at $90^{\circ} \mathrm{C}$. The dissolution behaviour showed evidence of re-precipitation phenomena, even after times as short as 28 days. Potential for improvement of NZP-based ceramics for HLW management is discussed.

\section{INTRODUCTION}

Sodium zirconium phosphate, $\mathrm{NaZr}_{2}\left(\mathrm{PO}_{4}\right)_{3}$ (NZP) is one of the candidate crystalline waste forms for the geological immobilization of high-level nuclear waste. Works at Pennsylvania State University [1-8] in the early 1980 s identified this as a near-single-phase system for incorporating PW-4b-type Purex waste. At high waste loadings, Cs formed a separate $\mathrm{CsZr}_{2}\left(\mathrm{PO}_{4}\right)_{3}$ phase that, is compatible with NZP and is highly durable in MCC-1 type tests [5]. Some monazite (a very durable natural mineral[9]) also formed, probably because the solid solubility limit of rare earth elements (REEs) in NZP had been exceeded.

The NZP structure consists of a three-dimensional network of $\mathrm{PO}_{4}$ tetrahedra sharing corners with $\mathrm{ZrO}_{6}$ octahedra, with the interstitial space partly occupied by $\mathrm{Na}$ ions [10]. Alkalis can substitute in the $\mathrm{Na}$ site. Divalent ions such as $\mathrm{Ca}, \mathrm{Ba}, \mathrm{Fe}, \mathrm{Mg}, \mathrm{Pb}$, and $\mathrm{Sr}$ substitute for two alkali ions [2]. Rare earth elements are assumed to enter the $\mathrm{Zr}$ site, with charge compensation being necessary for trivalent REEs. Tetravalent $\mathrm{Ti}$ substitutes freely on the $\mathrm{Zr}$ site. Trivalent $\mathrm{Pu}$ substitutes for $\mathrm{Zr}$, forming either $\mathrm{Na}_{3} \mathrm{Pu}_{2}\left(\mathrm{PO}_{4}\right)_{3}$ or $\mathrm{Na}_{3} \mathrm{Pu}\left(\mathrm{PO}_{4}\right)_{2}$ depending on the $\mathrm{Pu}$-to- $\mathrm{PO}_{4}$ ratio [11]. Hexavalent molibdenum was taken to substitute directly on the $P$ site, with appropriate charge compensation on other sites. Scanning electron microscopy (SEM) results indicated that the NZP phase contained all species of simulated waste ions [2], although it was not demonstrated that all of the radwaste entered this phase. Rather than carry out a detailed chemical accounting exercise to establish charge balance, the $\mathrm{Zr} / \mathrm{Na}$ and $\mathrm{P} / \mathrm{Na}$ ratios were varied and the phase assemblage was studied by X-ray diffraction (XRD) to establish the ratios giving as close to a single NZP-type phase as possible.

The fabrication of ceramic matrices with the NZP structure utilizes the principle of isomorphous and isodimorphous substitutions similar to those in natural minerals. Formation of a phosphate phase comprising all the major waste components of nuclear fuel cycle including actinides was demonstrated [12]. Alkali neptunium and plutonium phosphates $\mathrm{M}^{\mathrm{I}} \mathrm{An}_{2}\left(\mathrm{PO}_{4}\right)_{3}$ were found to crystallize in several isomorphous modifications. Americium and curium phosphates have structures similar to those of REE phosphates, which isomorphically substitute for $\mathrm{Zr}$ in a matrix. The phosphate NZP matrices may incorporate significant amounts of additional $\mathrm{Na}$ [12].

Tetragonal $\mathrm{NaPu}_{2}\left(\mathrm{PO}_{4}\right)_{3}$ was prepared to investigate radiation stability of the NZP matrices [13]. Samples in which the $\mathrm{Pu}$ was present as ${ }^{239} \mathrm{Pu}$ showed no perceptible changes during two years of observations in which doses of $9.1 \times 10^{13} \alpha$-events/mg were sustained, but material made with ${ }^{238} \mathrm{Pu}$ was rendered completely metamict after a dose of $9.3 \times 10^{15} \alpha$-events $/ \mathrm{mg}$. For comparison, zirconolite and perovskite in Synroc become metamict after doses of $4.7 \times 10^{15} \alpha$-events $/ \mathrm{mg}$ [13].

Ceramic phosphate matrices with the NZP structure containing simulated waste elements were investigated under hydrothermal conditions. The composition and structure of the ceramics showed no changes after reaction with hot water and aqueous chloride solutions at 200 to $400^{\circ} \mathrm{C}$ and 600 bars [14]. 
Russian HLWs are generally high in $\mathrm{Na}$, an element which is not easily accommodated in the Ti-based HLW ceramic Synroc [15]. However Synroc can be reformulated to include Na-bearing phases such as nepheline [16], additional perovskite [17] or freudenbergite [18]. Nepheline and freudenbergite contain around 22 and $9 \mathrm{wt} \% \mathrm{Na}_{2} \mathrm{O}$ respectively, while NZP contains $\sim 6 \mathrm{wt} \%$ of $\mathrm{Na}_{2} \mathrm{O}$.

The aims of present work were as follows: (1) prepare NZP-based waste forms by hot-pressing, rather than by sintering[1-8], and compare leaching and other relevant properties with those of Synroc; (2) investigate separate incorporation of $\mathrm{Cs} / \mathrm{Sr}$ and actinides as well as $\mathrm{PW}-4 \mathrm{~b}$ in NZP; (3) check compatibility of NZP with major Synroc phases to investigate the possibility of hybrid waste forms.

\section{EXPERIMENTAL METHODS}

Samples were prepared by methods similar to those used for Synroc. The precursor NZP phase was formed from tetrabutyl zirconate (TBZ) $\left[\mathrm{Zr}\left(\mathrm{OC}_{4} \mathrm{H}_{9}\right)_{4}\right], \mathrm{NaNO}_{3}$, and $85 \% \mathrm{H}_{3} \mathrm{PO}_{4}$, together with nitric acid-based mixtures of simulated waste, $\mathrm{Cs} / \mathrm{Sr}$ or $\mathrm{RE}$ nitrate solutions. After stir-drying, these mixtures were calcined in air at $700^{\circ} \mathrm{C}$. For consolidation, some preliminary work was done by simply pressing pellets and sintering in air at 1000 to $1200^{\circ} \mathrm{C}$.

Otherwise, stainless steel ( 316 SS) bellows were filled with calcined powder, sealed by welding on a lid, and hot uniaxially pressed (HUP) or isostatically pressed (HIP) at approximately $1100^{\circ} \mathrm{C}$. In the HUP process, a graphite susceptor is heated by radio-frequency power. With the design of our standard bellows and the small tap density of the precursor, the attainable HUP density was limited because the bellows' walls completely collapsed, thus offering significant resistance to further compaction of the ceramic powder. Though densities of about 92 to $94 \%$ of theoretical density were obtained, there was strong layering of the ceramic, which lacked mechanical integrity. These problems were removed by the use of an Eagle HIP, manufactured by International Pressure Systems, Inc., using highly pure argon as the pressure medium.

Archimedes' method was used to measure sample densities and porosities. Powder XRD measurements were made on a Siemens D-500 instrument, using Co radiation. Scanning electron microscopy was performed on a JEOL JXA-480 apparatus. Leaching measurements were made on $0.1 \mathrm{~g}$ of $37-63 \mu \mathrm{m}$ powders (from which the fines were carefully cleaned by washing in acetone) or approximately $1 \mathrm{~cm}$-sized machined, polished cuboids, in tightly-sealed $50 \mathrm{ml}$ Teflon jars at $90^{\circ} \mathrm{C}$ for periods of 7 and 28 days. On the basis of geometrical surface area, the surface area/volume ratio was about 1 and $0.2 \mathrm{~cm}^{-1}$ for the powders and cuboids, respectively. The powders were leached for different times, without sampling or replacement of the leach liquid between the beginning and finish of the run. While those from the cuboids were sampled at intermediate stages. The starting water $\mathrm{pH}$ was 5.0 in both cases.

\section{RESULTS ANDDISCUSSION}

\section{Preliminary Studies of Sintering}

The NZP precursors developed essentially full crystallinity during calcination at $700^{\circ} \mathrm{C}$. While this favors the formation of desired phases without the occurrence of metastable intermediate phases, some of the chemical driving force to form a dense product during hot-pressing or sintering is removed. By contrast however, $\mathrm{CsZr}_{2}\left(\mathrm{PO}_{4}\right)_{3}$ did not crystallise until sintering temperatures of about $1000^{\circ} \mathrm{C}$ were reached. The densities of samples cold-pressed at $\sim 100 \mathrm{Mpa}$ and sintered at 1000 to $1100^{\circ} \mathrm{C}$ reached around $90 \%$ but showed visual evidence of layering.

\section{Solid Solubilities of REEs and Mo in NZP}

As mentioned above, the REEs and Mo displayed some solid solubility in NZP, but experimental evidence of solubility limits was lacking. The following preparations were made up and sintered in air at 700 to $1100^{\circ} \mathrm{C}$ :
(a) $\mathrm{Na}_{(1-x)} \mathrm{Ca}_{(\mathrm{x})} \mathrm{Zr}_{(2-\mathrm{x})}(\mathrm{Nd} / \mathrm{Y})_{(\mathrm{x})}\left(\mathrm{PO}_{4}\right)_{3}$ and
(b) $\mathrm{NaZr}_{(2-x)} \mathrm{Y}_{(\mathrm{x})} \mathrm{P}_{(3-\mathrm{x})} \mathrm{Mo}_{(\mathrm{x})} \mathrm{O}_{12}$. 
For the (a) samples, the aim was to substitute the $\mathrm{Nd} / \mathrm{Y}$ on the $\mathrm{Zr}$ site, with Ca substituted on the $\mathrm{Na}$ site acting as the charge compensator. Mo was targeted for the $\mathrm{P}$ site in the (b) samples, and the charge compensator was $\mathrm{Y}$ on the $\mathrm{Zr}$ site. Only the NZP phase was observed in the (a) samples after heating at $700^{\circ} \mathrm{C}$. Heating at higher temperatures produced additional $\mathrm{ZrP}_{2} \mathrm{O}_{7}$, presumably due to loss of sodium by evaporation. After heating at $1100^{\circ} \mathrm{C}$, no sign of a separate $\mathrm{NdPO}_{4}$ (monazite) phase was observed in the Nd-doped samples with $\mathrm{x}=0.05$ and 0.1 , but for $\mathrm{x}>0.2$, an additional monazite phase was observed. In the Y-doped samples, similarly heated at $1100^{\circ} \mathrm{C}$, a separate $\mathrm{YPO}_{4}$ (xenotime) phase was observed in addition to NZP and $\mathrm{ZrP}_{2} \mathrm{O}_{7}$ for $\mathrm{x}=0.3$ and 0.4 , but not at $\mathrm{x}=0.1$ and 0.2. For the (b) samples, the results were very similar to those for the Y-doped (a) samples. The presence of Mo was confirmed by SEM studies of the $\mathrm{x}=0.4$ sample, showing that Mo volatilisation losses were not serious. However the very fine-grained nature of the powdered samples precluded conclusions about whether the dopant ions were really in solid solution in the NZP phase. To obtain more positive answers, it would be necessary to fire the samples in closed containers and perform TEM studies.

\section{Strategies for Waste Incorporation in NZP}

Firstly, heat-generating $\mathrm{Cs}$ and $\mathrm{Sr}$ partitioned from Purex waste were considered for incorporation in NZP. We employed the actual $\mathrm{Cs} / \mathrm{Sr}$ ratio in fission product waste, which is approximately 2:1 by weight. The designed total stoichiometry was $\mathrm{Na}_{0.5} \mathrm{Cs}_{0.2} \mathrm{Sr}_{0.15} \mathrm{Zr}_{2}\left(\mathrm{PO}_{4}\right)_{3}$, to give a total waste oxide loading of about $8 \mathrm{wt} \%$. As mentioned above, it was expected that Cs would form a distinct CsZP phase.

Secondly, actinide-rich wastes were considered. Tetravalent actinides would substitute for $\mathrm{Zr}$ (see above), but trivalent actinides are another issue. Such actinides were simulated by Gd and Nd. Two separate strategies were used: (1) Gd and Y were employed as simulations of the waste ions and it was aimed to substitute them in the $\mathrm{Zr}$ site, with half of the $\mathrm{Y}$ ions in the $\mathrm{Na}$ site. The total stoichiometry was $\mathrm{Na}_{0.5} \mathrm{Y}_{0.5} \mathrm{Gd}_{0.5} \mathrm{Y}_{0.5} \mathrm{Zr}\left(\mathrm{PO}_{4}\right)_{3}$, and the actinide waste loading was around $40 \mathrm{wt} \%$, assuming a molar substitution of $\mathrm{Gd}$ and $\mathrm{Y}$ for trivalent actinides. The substitution of the $\mathrm{Y}$ in the $\mathrm{Na}$ site was quite speculative, but the versatility of the NZP structure is shown by the fact that Na and one of the $\mathrm{Zr}$ ions can be completely replaced by a Nb $\mathrm{in}^{5+}$ [19]. (2) $\mathrm{Nd}$ was the waste ion simulant and it was substituted on the $\mathrm{Zr}$ site; $\mathrm{Ca}$ was the charge compensator on the $\mathrm{Na}$ site. Here the actinide waste loading was about $20 \mathrm{wt} \%$ on a molar substitution basis. PW-4b waste (see [2] and Table III) was also studied for incorporation in NZP at an oxide loading of $20 \mathrm{wt} \%$.

\section{Compatibility Studies}

Separate mixtures corresponding to equimolar mixtures of NZP and individual Synroc phases were mixed up, dried, calcined in air at $700^{\circ} \mathrm{C}$, then ground, pelletised and fired in air at $1100^{\circ} \mathrm{C}$. Rutile $\left(\mathrm{TiO}_{2}\right)+\mathrm{NZP}$ yielded a rutile-zirconia solid solution $+\mathrm{NZP}$; hollandite $\left(\mathrm{Ba}_{1.14}(\mathrm{Al}, \mathrm{Ti})_{2.28} \mathrm{Ti}_{6} \mathrm{O}_{16}\right)+\mathrm{NZP}$ yielded rutile $+\mathrm{NZP}+$ unknown phases; perovskite $\left(\mathrm{CaTiO}_{3}\right)+\mathrm{NZP}$ produced rutile + whitlockite $\left(\mathrm{Ca}_{3}\left(\mathrm{PO}_{4}\right)_{2}\right)+\mathrm{NZP}$, while zirconolite $\left(\mathrm{CaZrTi}_{2} \mathrm{O}_{7}\right)+\mathrm{NZP}$ gave baddeleyite $\left(\mathrm{ZrO}_{2}\right)$, rutile + unknown phases.

These results showed incompatibility of NZP and the Synroc phases. Experiments were also undertaken with the $\mathrm{Ti}$ analogue of NZP [7], but again compatibility was very limited; $\mathrm{Ba}$ and $\mathrm{Ca}$ entered the $\mathrm{Na}$ site of $\mathrm{NZP}$, and $\mathrm{Zr}$ partly replaced the $\mathrm{Ti}$ in the $\mathrm{Ti}$ analogue of $\mathrm{NZP}$, with residual rutile being formed.

\section{Hot-Pressing Studies}

Table I shows the phase assemblages and density/porosity results on various preparations Hiped at $1100^{\circ} \mathrm{C} / 100 \mathrm{MPa}$ for $2 \mathrm{~h}$. 
Table I. Densities and Phases Present in Hot Isostatically Pressed NZP-based Samples

\begin{tabular}{|c|c|c|c|c|}
\hline Sample & Composition & $\begin{array}{c}\text { Density } \\
\left(\mathrm{g} / \mathrm{cm}^{3}\right)\end{array}$ & $\begin{array}{c}\text { Porosity } \\
(\%)\end{array}$ & Phases Present \\
\hline 48 & $\mathrm{Na}_{0} \mathrm{Cs}_{02} \mathrm{Sr}_{015} \mathrm{Zr}_{2}\left(\mathrm{PO}_{4}\right)_{3}$ & 3.23 & 3.6 & $\mathrm{NZP}+\mathrm{ZP}$ \\
\hline 49 & $\mathrm{NaZr}_{2}\left(\mathrm{PO}_{4}\right)_{3}$ & $3.09^{*}$ & 3.6 & $\mathrm{NZP}+$ tr. ZP \\
\hline 50 & $\mathrm{NZP}+20 \mathrm{Wt} \% \mathrm{PW}_{-4 \mathrm{~b}}$ & 3.23 & 1.5 & $\mathrm{NZP}+\mathrm{Mz}+\mathrm{ZP}+\mathrm{CsZP}$ \\
\hline 51 & $\mathrm{Na}_{0,5} \mathrm{YZrGd}_{0,5}\left(\mathrm{PO}_{4}\right)_{3}$ & 3.76 & 3.3 & $\mathrm{NZP}+\mathrm{Xe}+\mathrm{ZP}$ \\
\hline 52 & $\mathrm{Na}_{0,5} \mathrm{Ca}_{05} \mathrm{Gd}_{0 ;} \mathrm{Zr}_{15}\left(\mathrm{PO}_{4}\right)_{3}$ & 3.43 & 3.8 & $\mathrm{NZP}+\mathrm{Mz}+\mathrm{ZP}$ \\
\hline
\end{tabular}

*theoretical density $=3.19 \mathrm{~g} / \mathrm{cm}^{3}$. Mz-monazite; Xe-xenotime; $\mathrm{ZP}-\mathrm{ZrP}_{2} \mathrm{O}_{7}$

Some SEM micrographs are shown in Figs. 1 through 4 . In nearly all cases the grain size was less than $2 \mu \mathrm{m}$ for xenotime and monazite. The NZP matrix in all samples consisted of grains more than $50 \mu \mathrm{m}$ in size. In samples \#48 and 50, a Sr-rich exsolution structure was present. In sample \#50, CsZP formed separate irregular variably-sized grains coexisting with the NZP matrix.

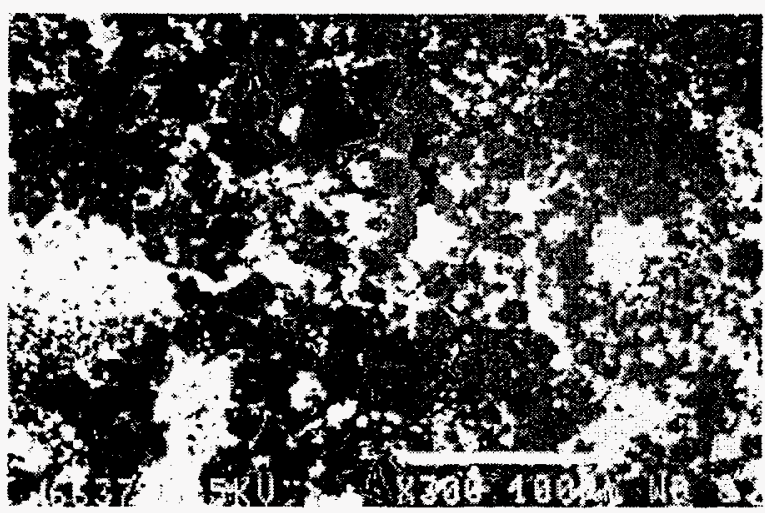

Fig. 1. Sample NZP-48. x300. white regions: separate $\mathrm{CsZr}_{2}\left(\mathrm{PO}_{4}\right)_{3}$ phase; grey: NZP matrix; dark grey spots inside of NZP grains: $(\mathrm{Na}, \mathrm{Sr}) \mathrm{Zr}_{2}\left(\mathrm{PO}_{4}\right)_{3}$; black: pores

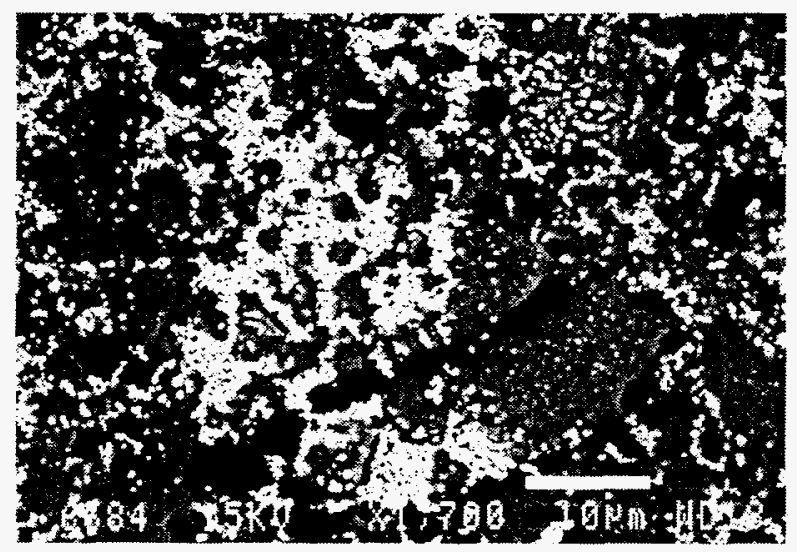

Fig. 3. Sample NZP-52 x1700. white: monazite; grey: NZP; black: $\mathrm{Ca}_{3}\left(\mathrm{PO}_{4}\right)_{2}$

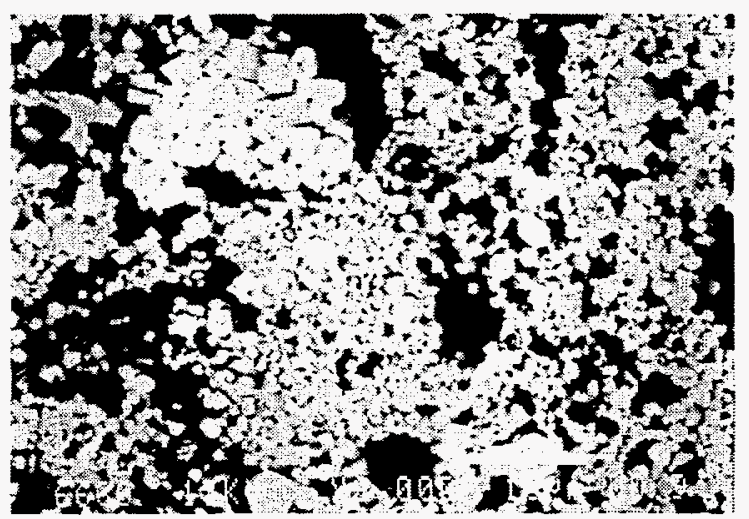

Fig. 2. Sample NZP-51. x2000. white: xenotime; black: NZP

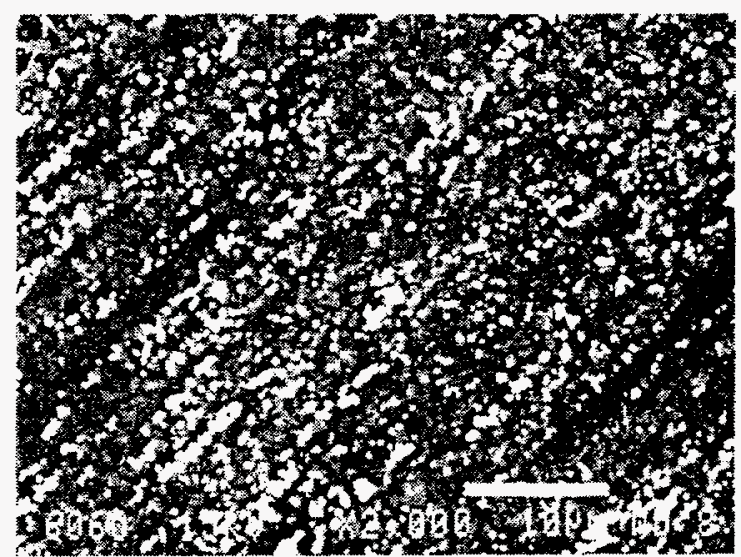

Fig. 4. Sample NZP-50 x2000. white: REphases; grey: NZP matrix; black: $\mathrm{ZrP}_{2} \mathrm{O}_{7}$ 
The phase assemblages were not unexpected given the previous work by the PSU group, and the results in Section II, which showed only limited solid solubilities of REEs and Mo in NZP, although the absence of a CsZP phase in sample 48 indicates some Cs solubility in NZP. Given that the materials densify to $\sim 90 \%$ of their theoretical value in sintering at around $1000^{\circ} \mathrm{C}$, it was puzzling why full densification did not occur during HIP. Possible reasons are the tendency of volatility of elements like $\mathrm{Na}$, or post-calcination resorption of atmospheric moisture, which was not removed during heating/evacuation prior to sealing the containers for HIPing.

Only the hot isostatically pressed samples were leach tested. Even then, only one or two pressings yielded samples that could be satisfactorily machined and polished. Thus sections of the samples were crushed to form 37-63 $\mu \mathrm{m}$ diameter powders (see above). A sample of Synroc-C was similarly prepared. Leach results are shown in Tables II and III below.

The 7- and 28-day leach rates of NZP-48 and NZP-49 were quite comparable with reference values for Synroc [18]. The corresponding data for the NZPs doped with simulated actinides (samples NZP-51/52) similarly gave results for the matrix elements and the rare earths which were comparable with those reported for Synroc. Data on NZP-50, which contained simulated PW-4b waste, were worse than Synroc by an order of magnitude for the more soluble elements, such as $\mathrm{Na}$, Cs and Mo. It was further clear from these data, for both the NZP-based materials and Synroc, that the fraction of some elements leached apparently decreased between 7 and 28 days. This observation suggested that reprecipitation of these elements had taken place at the longer leaching times, although XRD of the 28-day leached powders showed no significant differences from the data obtained from the unleached samples.

The data on Synroc were better than reference data obtained on polished samples [15] by factors of 1-10 and showed the usual decrease of leach rate with time for all elements, exept calcium which differed by only factor of 2 .

Table II. Solution Leach Rates at $90^{\circ} \mathrm{C}$ of 37-63 $\mu \mathrm{m}$ Diameter Samples Prepared from Hot Isostatically Pressed NZP-based Samples

\begin{tabular}{|c|c|c|c|c|c|c|c|c|c|c|c|c|c|}
\hline & \multicolumn{9}{|c|}{ Leach rate $\left(\mathrm{g} / \mathrm{m}^{2} /\right.$ day $)$} \\
\cline { 2 - 15 } & \multicolumn{3}{|c|}{ NZP-49 } & \multicolumn{3}{c|}{ NZP-48 } & \multicolumn{3}{c|}{ NZP-51 } & \multicolumn{3}{c|}{ NZP-52 } \\
\hline Element & $\mathrm{wt} \%$ & 7 days & 28 days & $\mathrm{wt} \%$ & 7 days & 28 days & $\mathrm{wt} \%$ & 7 days & 28 days & $\mathrm{wt} \%$ & 7 days & 28 days \\
\hline $\mathrm{Na}$ & 4.7 & 0.12 & 0.03 & 2.2 & 0.012 & 0.005 & 2.1 & 0.01 & 0.005 & 2.2 & 0.008 & 0.002 \\
\hline $\mathrm{Cs}$ & 0 & & & 5.1 & 0.02 & 0.002 & & & & & & \\
\hline $\mathrm{Sr}$ & 0 & & & 2.5 & 0.01 & 0.003 & & & & & & \\
\hline $\mathrm{Ca}$ & 0 & & & 0 & & & & & & 3.8 & 0.022 & 0.01 \\
\hline $\mathrm{Gd}$ & 0 & & & 0 & & & 13.8 & $7 \times 10^{-7}$ & $2 \times 10^{-7}$ & & & \\
\hline $\mathrm{Y}$ & 0 & & & 0 & & & 16.1 & $2 \times 10^{-6}$ & $2 \times 10^{-7}$ & & & \\
\hline $\mathrm{Nd}$ & 0 & & & 0 & & & & & & 13.7 & $7 \times 10^{-7}$ & $2 \times 10^{-7}$ \\
\hline $\mathrm{Zr}$ & 3.77 & $6 \times 10^{-5}$ & $3 \times 10^{-7}$ & 35.2 & $3 \times 10^{-6}$ & $1 \times 10^{-7}$ & 13.5 & $2 \times 10^{-6}$ & $2 \times 10^{-7}$ & 26.1 & $8 \times 10^{-7}$ & $1 \times 10^{-8}$ \\
\hline $\mathrm{P}$ & 18.9 & 0.04 & 0.1 & 17.9 & 0.04 & 0.01 & 16.9 & 0.014 & 0.01 & 17.7 & 0.004 & 0.002 \\
\hline $\begin{array}{c}\text { weight } \\
\text { loss \% }\end{array}$ & & 18.4 & 5.3 & & 27.1 & 5.2 & & 38.8 & 21.2 & & 31.7 & 9.4 \\
\hline Final pH & & 4.76 & 5.29 & & 4.14 & 5.28 & & 5.90 & 4.76 & & 5.25 & 4.76 \\
\hline
\end{tabular}


Table III. Leaching Results on 37-63 $\mu \mathrm{m}$ Diameter Hot Isostatically Pressed NZP Ceramics with $20 \mathrm{wt} \% \mathrm{HLW}$ and Synroc-C with $15 \mathrm{wt} \% \mathrm{HLW}$

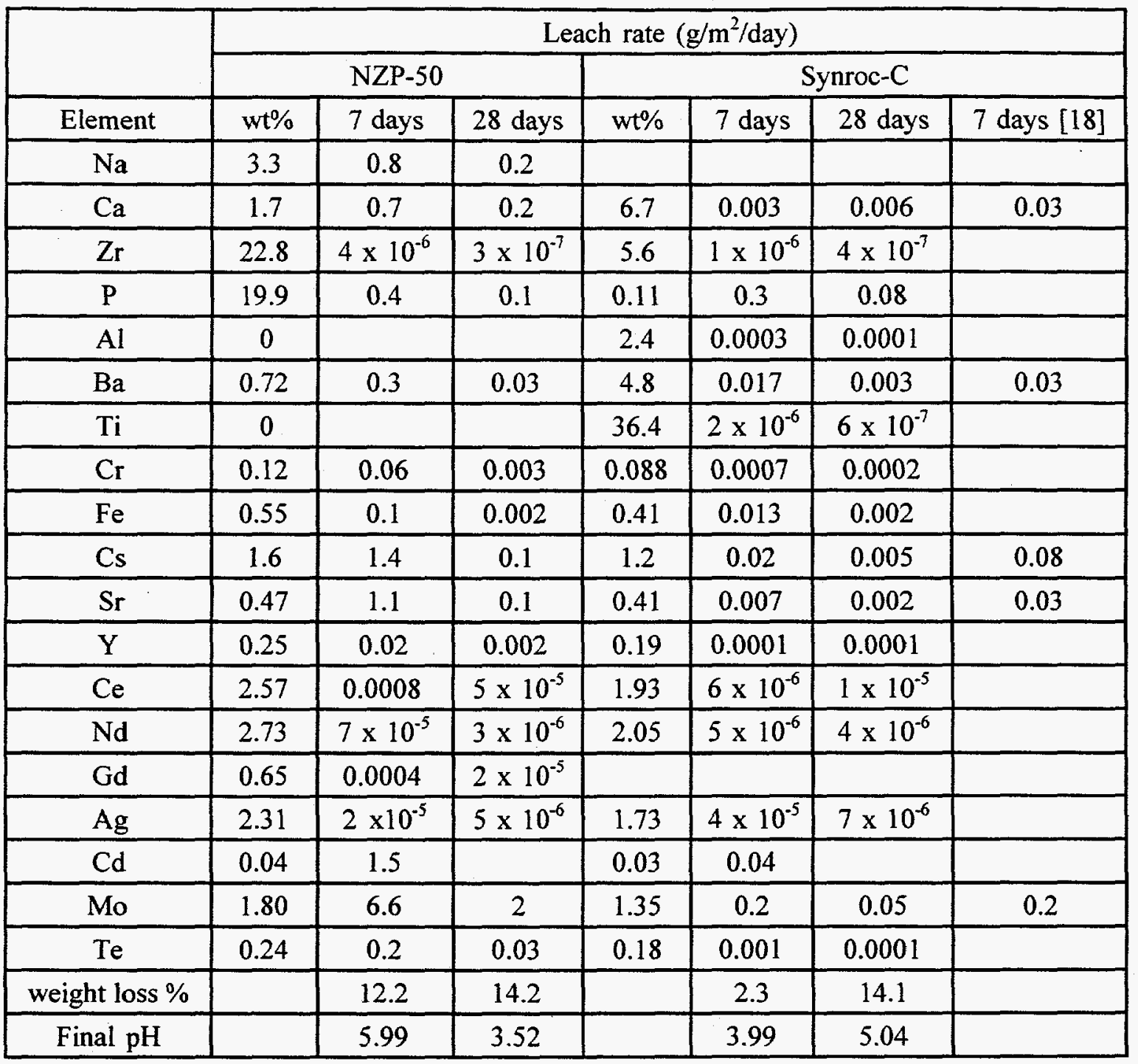

\section{CONCLUSIONS AND SUGGESTIONS FOR FURTHER WORK}

On the basis of the current work, dense NZP-based waste ceramics have chemical durabilities within an order of magnitude of that of Synroc, although the interpretation of the NZP leach results for most of the NZP samples, except NZP-50, appears to involve significant re-precipitation effects even after 28 days in the tests performed here, because the weight losses in 7-day tests exceeded those in the 28-day tests. The NZP-based formulations also lack a key advantage of the Synroc approach, that is there is no known resistant naturally occurring NZP analogue mineral, to construct a prima facie case for long-term aqueous durability: this imposes additional pressure on performing real-time leach experiments that can enable long-term predictions of leach resistance. Potential for improving of the NZP-based material is seen in the following areas: (1) development of denser precursors; (2) obtaining a more extensive data base on solid solubility of radwaste ions in NZP- this would allow more careful overall phase design; (3) optimising the hot-pressing sequence, including redox conditions. 


\title{
ACKNOWLEDGEMENTS
}

We wish to acknowledge the Department of Industry, Trade and Commerce, Canberra, Australia, for financial support, A. E. Ringwood for helpful discussions, J. Weir for carrying out the leach tests, T. Nicholls for specimen preparation, P. J. Angel and S. S. Moricca for performing the hot-pressings, and S. Leung for assistance with scanning electron microscopy.

\section{REFERENCES}

1. E. R. Vance and T. Adl, in Scientific Basis for Nuclear Waste management, Vol. 3, Ed., S. V. Topp, Plenum, New York, 163-71 (1981).

2. R. Roy, L. J. Yang, J. Alamo, and E. R. Vance, in Scientific Basis for Nuclear Waste Management VI, Ed., D.G. Brookins, North-Holland, Amsterdam, 15-21 (1983).

3. L. J. Yang, S. Komarneni, and R. Roy, in Scientific Basis for Nuclear Waste Management VII, Ed., G.L. McVay, North-Holland, Amsterdam, 567-74 (1984).

4. B. E. Scheetz, S. Komarneni, W. Fajun, L. J. Yang, M. Ollinen and R. Roy, in Scientific Basis for Nuclear Waste Management VII, Eds. C. M. Jantzen, J. A. Stone, and R. C. Ewing, Materials Research Society, Pittsburgh, PA, USA, 903-10 (1985).

5. R. Roy, E. R. Vance, and J. Alamo, $\mathrm{CsZr}_{2}\left(\mathrm{PO}_{4}\right)_{3}$, Mater. Res. Bull. 17, 585-9 (1982).

6. L. J. Yang, S. Komarneni and R. Roy, in Advances in Ceramics Vol. 8, Eds., G. G. Wicks and W. A. Ross, American Ceramic Society, Columbus, OH, USA, 368-76 (1984).

7. L. J. Yang, S. Komarneni, and R. Roy, 255-62.

8. E. R. Vance and F. J. Ahmad, in Scientific Basis for Nuclear Waste Management VII, Ed., D. G. Brookins, North-Holland, Amsterdam, 105-12 (1983).

9. G. J. McCarthy, W. B. White and D. E. Pfoertsch, Mater. Res. Bull., 13, 1239-45 (1978).

10. H.Y-P Hong, Mater.Res. Bull 11, 173-80 (1976).

11. A. A. Burnaeva, Yu. F. Volkov, A. I. Krjukova, Radiokhimiya 36, 289-294 (1994).

12. A. I. Krukova, Yu. F. Volkov, V. N. Zyryanov, G. N. Kazantzev. I. A. Kulikov, S. G. Samoilov, Proceedings of 3rd Annual Conference of Nuclear Society International. Moscow, Sept. 14-18, Management with Radioactive Waste, 673-674, St-Petersburg (1992).

13. A. I. Orlova, G. Yu. Artemjeva, L. Yu. Masterova, V. I. Petkov, A. A. Harlamova, Yu. F. Volkov, V. N. Zyryanov, G. N. Kazantzev, S. G. Samoilov, I. A. Kulikov, and S. V. Stefanovsky, Abstracts of 4th Annual Scientific and Technology Conference of Nuclear Society "Nuclear Energy and Human Safety" NE-93, June 28-July 2, 1993, part 2, 877-878, Nizhniy Novgorod, (1993).

14. A. I. Orlova, V. N. Zyryanov, A. R. Kotelnikov, V. T. Demarin, and E. V. Rakitina, Radiokhimiya 6, 120-126 (1993).

15. A. E. Ringwood, S. E. Kesson, N. G. Ware, W. Hibberson and A. Major, Nature (London) 278, 21923 (1979).

16. A. E. Ringwood, S. E. Kesson and N.G. Ware, in Scientific Basis for Nuclear Waste Management Vol. 2., Ed., C.J.M. Northrup, Plenum, New York and London, 265-72 (1980).

17. E. R. Vance and G. J. Thorogood, J.Amer. Ceram. Soc. 74, 854-5 (1991).

18. A. E. Ringwood, S. E. Kesson, K. D. Reeve, D. M. Levins, and E. J. Ramm, in Radioactive waste forms for the future, Eds., W.Lutze and R.C. Ewing, Elsevier, New York, 233-334 (1988).

19. I. Yamai and T. Ota, J. Amer. Ceram. Soc., 76, 487-91 (1993).

\section{DISCLAIMER}

\begin{abstract}
This report was prepared as an account of work sponsored by an agency of the United States Government. Neither the United States Government nor any agency thereof, nor any of their employees, makes any warranty, express or implied, or assumes any legal liability or responsibility for the accuracy, completeness, or usefulness of any information, apparatus, product, or process disclosed, or represents that its use would not infringe privately owned rights. Reference herein to any specific commercial product, process, or service by trade name, trademark, manufacturer, or otherwise does not necessarily constitute or imply its endorsement, recommendation, or favoring by the United States Government or any agency thereof. The views and opinions of authors expressed herein do not necessarily state or reflect those of the United States Government or any agency thereof.
\end{abstract}

